\title{
FAILURE OF ORALLY ADMINISTERED PERCHLORATE TO AFFECT DECIDUOMA FORMATION OR PREGNANCY IN THE RAT
}

\author{
K. BROWN-GRANT* \\ Department of Human Anatomy, South Parks Road, Oxford
}

(Received 4th March 1966)

\begin{abstract}
Summary. Administration of $1 \%$ potassium perchlorate solution by mouth from Day 2 to Day 8 has no effect on the course of gestation in pregnant rats or on the decidual response to trauma in pseudopregnant rats.
\end{abstract}

\section{INTRODUCTION}

A raised uterus-plasma $(u / p)$ concentration ratio for radio-iodide is observed during a limited period of early pregnancy immediately before implantation of the blastocysts occurs in rats and in mice. The possibility that a raised endometrial iodide concentration was necessary for implantation was tested by administering $0.25 \% \mathrm{KClO}_{4}$ solution (which inhibits the development of a raised $u / p$ ratio for radio-iodide) during early pregnancy, but no effect on the course of pregnancy was observed (Brown-Grant, 1965). An increase in the $u / p$ ratio for ${ }^{131} \mathrm{I}$ also occurs in pseudopregnant rats; the necessary conditions for the decidual reaction and blastocyst implantation may not be identical and so, despite the negative results obtained in the earlier experiments, the effect of the administration of perchlorate on deciduoma formation in response to trauma in the pseudopregnant rat has been studied.

\section{MATERIALS AND METHODS}

Adult female Wistar rats were used; in the first experiment the animals were from the laboratory colony, but in the second experiment on deciduoma formation and in the experiments on pregnant rats the animals used were obtained from Animal Suppliers (London) Ltd, Finchley, London, N.12. All male rats were from the laboratory colony. Daily vaginal smears were taken and, at prooestrus, individual rats were placed with a single intact or vasectomized male overnight. Copulation was confirmed by the presence of spermatozoa in the vaginal smear next day or by the presence of a copulation plug, and smears were not taken after this day which is Day 0 of pregnancy or pseudopregnancy. On the morning of Day 2 the animals were moved to metabolism cages where they remained until the morning of Day 8 of pregnancy or, in the case of the

\footnotetext{
* Locke Research Fellow of the Royal Society.
} 
experiments on deciduoma formation, until they were killed. While in the metabolism cages a 0.25 or $1.0 \%(\mathrm{w} / \mathrm{v})$ solution of either potassium chloride or potassium perchlorate in tap-water was given instead of the tap-water normally supplied and the daily fluid intake was measured. From the volume of fluid drunk daily the mean intake of the salt as $\mathrm{mg} / \mathrm{rat} /$ day was calculated.

Pregnant rats were weighed at intervals of 6 days and on Day 20 animals that were clearly pregnant were placed in individual cages and inspected twice daily until the litter was born, when the duration of pregnancy, number and sex of the litter were recorded. Rats not obviously pregnant on Day 20 were killed and the uteri carefully examined for evidence of old implantation sites. Deciduoma formation was stimulated by traumatizing the entire length of the anti-mesometrial surface of one uterine horn by a knife-tipped needle inserted into the lumen of the uterus under ether anaesthesia, following the technique described by De Feo (1963). In the first experiment rats were traumatized on Day 3 and killed on Day 7 and in the second experiment traumatized on Day 4 and killed on Day 8. On the day of killing, rats were injected with methylthiouracil $45 \mathrm{~min}$ before the injection of $5 \mu \mathrm{c}$ of $\mathrm{Na}^{131} \mathrm{I}$ and $2 \mathrm{hr}$ later blood, thyroid, oviduct, uterus and fore-stomach samples were obtained for the determination of tissue-plasma concentration ratios for ${ }^{131} \mathrm{I}$. Full details of the method have been published recently (Brown-Grant, 1965). Thyroid-plasma and stomach-plasma ratios are abbreviated to $t / p$ and $s / p$ ratios in the text and in tables. The weight of the traumatized and control uterine horns was measured and the decidual response recorded by expressing the weight of the traumatized horn as a percentage of the weight of the control horn.

Values in text and tables are group means \pm standard error of the mean; the $P$ values quoted were obtained in the $t$-test.

\section{RESULTS}

Effect of $0 \cdot 25 \% \mathrm{KClO}_{4}$ on deciduoma formation

Rats receiving $0.25 \% \mathrm{KCl}$ or $\mathrm{KClO}_{4}$ solution to drink were traumatized on Day 3 and killed on Day 7; the results obtained are given in Table 1. No effect on deciduoma formation was observed, but the experiment was unsatisfactory in that the decidual response was very variable in both $\mathrm{KCl}$ - and $\mathrm{KClO}_{4}$ treated groups. In addition, tissue-plasma ratios for ${ }^{131} \mathrm{I}$ were rather higher in the perchlorate-treated rats than in an earlier study (Brown-Grant, 1965). The effectiveness of $0.25 \%$ and $1 \% \mathrm{KClO}_{4}$ solutions by mouth for 1 or 5 days in reducing tissue plasma ratios for ${ }^{131} \mathrm{I}$ was compared in male rats; the results given in Table 2 show that tissue-plasma ratios were slightly lower in rats given $1 \% \mathrm{KClO}_{4}$ solution to drink although the differences were not statistically significant $(P>0.05)$. The experiment on deciduoma formation was repeated with $1 \%$ instead of $0.25 \%$ salt solutions and the operation was performed a day later.

Effect of $1 \% \mathrm{KClO}_{4}$ solution on deciduoma formation

Rats were traumatized on Day 4 and killed on Day 8 and ${ }^{131} \mathrm{I}$ ratios determined; the results are given in Table 1. In this experiment there was a massive 


\begin{tabular}{|c|c|c|c|c|c|}
\hline 일 & \multirow{5}{*}{ 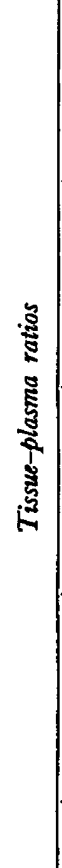 } & $\frac{\stackrel{8}{ \pm}}{+1}$ & $\begin{array}{l}\text { Nొ } \\
\dot{0} \\
+1 \\
\mathscr{\phi} \\
\dot{0}\end{array}$ & $\begin{array}{l}\stackrel{+}{+} \\
+1 \\
\stackrel{+}{0} \\
\dot{\infty}\end{array}$ & $\begin{array}{l}\frac{t}{\dot{0}} \\
+1 \\
\overrightarrow{0} \\
\dot{0}\end{array}$ \\
\hline 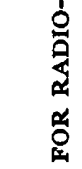 & & $\begin{array}{l}\stackrel{\infty}{\infty} \\
\dot{\phi} \\
+1 \\
\stackrel{8}{\$} \\
\dot{N}\end{array}$ & $\begin{array}{l}0 \\
\dot{0} \\
+1 \\
0 \\
0 \\
0\end{array}$ & $\begin{array}{l}\varphi \\
\dot{0} \\
+1 \\
0 \\
\stackrel{0}{\dot{m}}\end{array}$ & $\begin{array}{l}0 \\
0 \\
\dot{0} \\
+1 \\
+1 \\
0 \\
0\end{array}$ \\
\hline 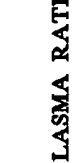 & & $\begin{array}{l}0 \\
0 \\
\dot{0} \\
+1 \\
0 \\
0 \\
0\end{array}$ & 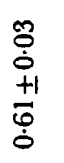 & 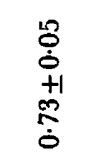 & 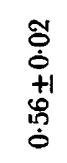 \\
\hline 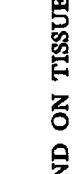 & & $\begin{array}{l}\stackrel{?}{\vec{\nabla}} \\
+1 \\
\infty \\
\dot{m} \\
\dot{m}\end{array}$ & $\begin{array}{l}\stackrel{0}{0} \\
+1 \\
\stackrel{+}{-}\end{array}$ & 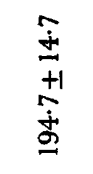 & $\frac{\stackrel{9}{\dot{+}}}{\stackrel{+1}{\sim}}$ \\
\hline & & $n$ & + & os & $a$ \\
\hline 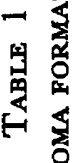 & 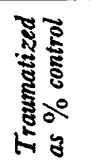 & $\begin{array}{l}\mathbb{N} \\
+1 \\
0 \\
0 \\
\infty\end{array}$ & 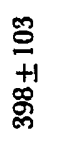 & $\begin{array}{l}n \\
n \\
+1 \\
8 \\
0 \\
\varrho\end{array}$ & 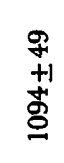 \\
\hline 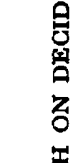 & 胥 & $\begin{array}{l}\bar{\infty} \\
+1 \\
\stackrel{\infty}{\infty}\end{array}$ & $\begin{array}{l}\bar{\sigma} \\
+1 \\
\text { 䔍 }\end{array}$ & 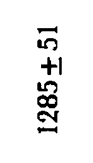 & 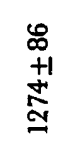 \\
\hline 总 & 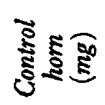 & $\begin{array}{l}+ \\
+1 \\
0\end{array}$ & $\begin{array}{l}\infty \\
+1 \\
\stackrel{0}{0}\end{array}$ & $\begin{array}{l}\tilde{+} \\
\stackrel{+1}{\Xi}\end{array}$ & $\begin{array}{l}n \\
\stackrel{+1}{0} \\
ٍ\end{array}$ \\
\hline 武 & 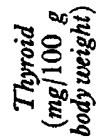 & $\begin{array}{l}\stackrel{0}{0} \\
+1 \\
\dot{n}\end{array}$ & $\begin{array}{l}\varphi \\
\dot{0} \\
+1 \\
+1 \\
\infty\end{array}$ & $\begin{array}{l}\mathcal{N} \\
\dot{0} \\
+1 \\
\stackrel{+}{\dot{T}}\end{array}$ & 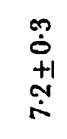 \\
\hline & : & ๙ & 8 & 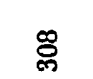 & $\stackrel{\mathscr{Z}}{*}$ \\
\hline 5 & $\dot{2}$ & $\infty$ & $\infty$ & $a$ & o \\
\hline 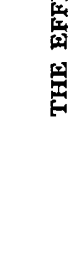 & 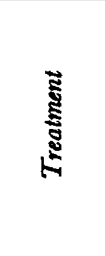 & 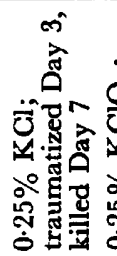 & 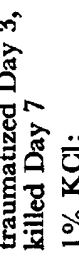 & 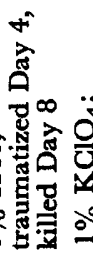 & 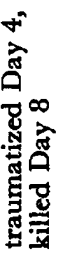 \\
\hline
\end{tabular}


and uniform decidual reaction in all rats. Thyroid hypertrophy was significant in this experiment $(P<0.001)$.

Effect of $1 \% \mathrm{KClO}_{4}$ solution on pregnancy

Rats on $1 \% \mathrm{KClO}_{4}$ have a much higher intake of salt than those on $0.25 \%$; the pregnancy experiment was, therefore, repeated on rats receiving $1 \% \mathrm{KCl}$ or $1 \% \mathrm{KClO}_{4}$ from Day 2 to Day 8 of pregnancy. Mean values ( $\mathrm{KCl}$ controls first) for salt intake were 371 and $237 \mathrm{mg} / \mathrm{rat} /$ day; pregnancy was successful

TABLE 2

EFFECTS OF ORAL ADMINISTRATION OF $0 \cdot 25 \%$ OR $1 \cdot 0 \%$ POTASSIUM PERCHLORATE SOLUTION FOR 1 OR 5 DAYS ON THYROID WEIGHT AND TISSUE-PLASMA RATIOS FOR RADIO-IODIDE IN MALE RATS

\begin{tabular}{|c|c|c|c|c|c|}
\hline Treatment & No. & $\begin{array}{l}\text { Salt } / \\
\text { rat/day } \\
(m g)\end{array}$ & $\begin{array}{c}\text { Thyroid weight } \\
\text { (mg/ } 100 \mathrm{~g} \\
\text { body weight })\end{array}$ & $\begin{array}{c}\text { t/p concentration } \\
\text { ratio }\end{array}$ & $\begin{array}{c}s / p \text { concentration } \\
\text { ratio }\end{array}$ \\
\hline $\begin{array}{l}\text { Controls } 0 \cdot 25 \% \mathrm{KCl} \\
\text { for } 5 \text { days }\end{array}$ & 7 & 66 & $5 \cdot 2 \pm 0 \cdot 3$ & $80 \cdot 9 \pm 11 \cdot 4$ & $7 \cdot 46 \pm 1 \cdot 01$ \\
\hline $\begin{array}{l}0 \cdot 25 \% \mathrm{KClO}_{4} \\
\quad \text { for } 1 \text { day }\end{array}$ & 5 & 77 & $4 \cdot 7 \pm 0 \cdot 4$ & $1.8 \pm 0.4$ & $0.97 \pm 0.13$ \\
\hline $\begin{array}{l}0.25 \% \mathrm{KClO}_{4} \\
\text { for } 5 \text { days }\end{array}$ & 7 & 68 & $5.9 \pm 0.3$ & $4 \cdot 1 \pm 0 \cdot 8$ & $0.85 \pm 0.11$ \\
\hline $\begin{array}{l}1 \% \mathrm{KClO}_{4} \\
\text { for } 1 \text { day }\end{array}$ & & 250 & $5 \cdot 4 \pm 0.4$ & $1 \cdot 0 \pm 0 \cdot 1$ & $0.67 \pm 0.04$ \\
\hline $\begin{array}{l}1 \% \mathrm{KClO}_{4} \\
\text { for } 5 \text { days }\end{array}$ & $\begin{array}{l}5 \\
7\end{array}$ & 216 & $6 \cdot 1 \pm 0 \cdot 2$ & $2 \cdot 5 \pm 0.3$ & $0.62 \pm 0.03$ \\
\hline
\end{tabular}

(birth of a live litter) in seven of eleven controls and eight of eleven treated rats and mean litter sizes were 8.9 and 8.0 ; duration of pregnancy was 22 days in all control rats and 22 days in six treated rats and 23 days in the other two. None of the four control or three treated rats killed 20 days after mating had any visible implantation sites in the uterus, suggesting that in all cases pregnancy had failed before implantation. No significant differences between rats receiving $1 \% \mathrm{KClO}_{4}$ and those receiving $1 \% \mathrm{KCl}$ were established.

\section{CONCLUSION}

The conclusion drawn from these experiments is that when the end result of the action of the iodide concentrating mechanism of the rat uterus-a raised endometrial iodide concentration during Days 3 to 5 of pregnancy or pseudopregnancy-is abolished by the oral administration of $1 \%$ potassium perchlorate solution, there is no evidence of interference with the course of pregnancy or with the decidual response to trauma.

\section{ACKNOWLEDGMENTS}

This work was supported by a grant for technical assistance from the Medical Research Council and for research expenses from the Royal Society. This sup- 
port is gratefully acknowledged as is the valuable assistance of $\mathrm{Mr} \mathrm{M}$. Sherwood in carrying out these experiments.

\section{REFERENCES}

Brown-Grant, K. (1965) The metabolism of iodide by the thyroid gland and by the uterus during early pregnancy in the rat. F. Physiol., Lond. 176, 73.

De Feo, V. J. (1963) Temporal aspect of uterine sensitivity in the pseudopregnant or pregnant rat. Endocrinology, 72, 305. 